\author{
INAPLICABILITATEA ACTELOR NORMATIVE \\ PRIVIND SUSPENDAREA LEGALĂ A \\ EXECUTĂRII SILITE ȘI EȘALONAREA PLĂȚII \\ SUMELOR PREVĂZUTE PRIN HOTĂRÂRI \\ JUDECĂTOREȘTI AVÂND CA OBIECT \\ DESPĂGUBIRI REZULTATE ÎN URMA \\ CONCEDIERII NELEGALE
}

DOI: $\quad 10.24193$ /SUBBiur.66(2021).3.3

Data publicării online:

31.12 .2021

\title{
Șerban MIRCIOIU*
}

Rezumat: Prezentul articol urmărește să prezinte modalitatea în care are loc executarea silită a hotărârilor judecătorești având ca obiect despăgubiri rezultate în urma concedierii nelegale respectiv acordarea unor drepturi de natură salarială stabilite în favoarea personalului din sectorul bugetar, devenite executorii

Instanțele de judecată, în măsura în care apreciază că a avut loc o decizie nelegală de încetare a contractului individual de muncă, pronunță hotărâri judecatărești prin care admit acțiunea civilă formulată de către reclamant împotriva pârâtului, instituție sau autoritate publică, urmând a dispune anularea deciziei de încetare a contractului individual de muncă emisă de pârât, iar față de prevederile art. 80 din Codul muncii dispun reintegrarea în funcția avută anterior emiterii deciziei menționate și obligarea pârâtului la plata unei despăgubiri egale cu salariile indexate, majorate și reactualizate, începând cu data deciziei de încetare a contractului

* Doctor în drept, avocat, Baroul Cluj, lector I.N.P.P.A., serban.mircioiu@avocatbaras.ro. 
individual de muncă emisă de pârât și până la reintegrarea efectivă. Ulterior creditorii se adresează executorului judecătoresc solicitând punerea în executare silită, împotriva debitorului a sumei integrale stabilite prin hotărârea judecătorească - titlu executoriu iar debitorii, instituțiile și autoritățile publice formulează, de regulă, contestație la executare, invocă drept argument principal al contestației la executare incidența actelor normative care prevăd faptul că, drepturile de natură salarială ce fac obiectul executării silite se plătesc eșalonat.

Incidența actelor normative care stipulează eșalonarea la plată a sumelor prevăzute prin hotărâri judecătorești în favoarea personalului din instituțiile și autoritățile publice în cazul despăgubirilor acordate conform art. 80 C.m., în caz de concediere ilegală, este exclusă.

Natura juridică a drepturilor câş̦tigate de către creditori prin titlurile executorii nu reprezintă drepturi de natură salarială ci despăgubiri compensatorii pentru încetarea nelegală a raporturilor de muncă.

În concluzie, actele normative care stabilesc plata eșalonată a drepturilor de natură salarială stabilite în favoarea personalului din instituțiile și autoritățile publice și care suspendă executarea hotărârilor judecătorești nu au aplicabilitate în ipoteza drepturilor câștigate de către personalul din instituțiile și autoritățile publice prin titluri executorii ce reprezintă despăgubiri compensatorii pentru încetarea nelegală a raporturilor de muncă, în aceste cazuri sumele datorate creditorilor urmând a fi achitate integral.

Cuvinte cheie: punerea în executare silită a despăgubirilor rezultate în urma concedierii nelegale; despăgubiri egale cu salariile indexate, majorate și reactualizate, drepturi de natură salarială; suspendarea legală a executării silite și eșalonarea la plată a sumelor prevăzute prin hotărâri judecătorești. 


\author{
DIE NICHTANWENDUNG DER \\ VERSCHIEDENEN RECHTSAKTEN \\ HINSICHTLICH DER
}
AUFHEBUNG DER ZWANGSVOLLSTRECKUNG
DER BETRÄGE ENTSTANDEN AUS URTEILEN,
DIE

\begin{abstract}
ALS GEGENSTAND ENTSCHÄDIGUNG UND
SCHADENSERSATZ WEGEN UNWIRKSAMER

KÜNDIGUNG
\end{abstract}

HABEN

Kurzfassung: Der nationale Gesetzgeber hat verschiedene Rechtsakte erlassen, hinsichtlich der Aufhebung der Zwangsvollstreckung der Beträge entstanden aus Urteilen der Gerichte, die als Gegenstand Ansprüche mit Gehaltscharakter der Staatsangestellte haben. Diese Aufhebung der Zwangsvollstreckung ist im Fall der Urteile, die als Gegenstand Entschädigung und Schadensersatz wegen unwirksamer Kündigung haben, ist nicht anwendbar, weil die Rechtsnatur dieser Urteile unterschiedlich ist. Diese Urteile haben als Gegenstand nicht keine Ansprüche mit Gehaltscharakter, sondern Entschädigung und Schadensersatz wegen unwirksamer Kündigung. Nur bei Ansprüchen mit Gehaltscharakter wird die Zwangsvollstreckung aufgehoben. Urteile, die als Gegenstand Ansprüche mit Gehaltscharakter haben, unterscheiden sich in wesentlicher Weise von den Urteilen, die als Gegenstand Entschädigung und Schadensersatz wegen unwirksamer Kündigung haben. Im

letzteren Fall ist die Aufhebung der Zwangsvollstreckung rechtswidrig und der Gerichtsvollzieher muss die getroffenen Zwangsvollstreckungsmaßnahmen nicht aufheben.

Stichwörter: die Zwangsvollstreckung der Beträge entstanden aus Urteilen, die als Gegenstand Entschädigung und Schadensersatz wegen unwirksamer Kündigung haben, Ansprüche mit Gehaltscharakter, die Aufhebung der Zwangsvollstreckung. 


\title{
IRRELEVANCE OF THE LAWS ON LEGAL SUSPENSION OF THE ENFORCEMENT AND THE PAYMENT SCHEDULING OF THE AMOUNTS PROVISIONED BY COURT ORDERS
} HAVING AS OBJECT COMPENSATIONS RESULTED SUBSEQUENT TO ILLEGAL DISMISSAL

\begin{abstract}
The purpose of this article is to set out the way enforcement of court orders is taking place with regard to compensation resulting from illegal dismissal and the granting of salary entitlements established in favour of staff in the budgetary sector, which have become enforceable.

The courts, in so far as they consider that an unlawful decision to terminate the individual employment contract has taken place, shall give judgment in admitting the civil action brought by the applicant against the defendant, institution or public authority, ordering the annulment of the termination decision of the individual employment contract issued by the defendant, and, in relation to the provisions of art. 80 of the Romanian Labour Code provides for the reinstatement in the position held before the issuance of the said decision and obliges the defendant to pay compensation equal to the indexed, increased and updated salaries, starting with the date of the decision to terminate the individual employment contract issued by the defendant and until effective reinstatement. Subsequently, the creditors address the bailiff requesting the enforcement, against the debtor, of the full amount established by the court order - enforceable title and the debtors, institutions and public authorities usually file an appeal against enforcement, invoking as main argument of such appeal against enforcement the incidence of the norms that stipulate that the salary rights that are subject to enforcement are paid in instalments.

The incidence of the laws stipulating the payment scheduling of the amounts provided by court orders in favour of the personnel from the public institutions and authorities in case of the compensations granted according to art. 80 Romanian C.m., in case of illegal dismissal, is excluded.

The legal nature of the rights earned by creditors through enforceable titles does not represent salary rights but compensatory damages for the illegal termination of employment.

In conclusion, the pieces of legislation that establish the scheduled payment of salary rights established in favour of staff in public institutions and authorities and that suspend the execution of court orders are not applicable in the case of rights
\end{abstract}


earned by staff in public institutions and authorities by enforceable titles representing compensatory damages for the illegal termination of employment, in these cases the amounts due to creditors will be paid in full.

Key-words: enforcement of damages resulting from illegal dismissal; compensation equal to indexed, increased and updated salaries, salary rights; the legal suspension of the forced execution and the payment scheduling of the amounts provided by court orders.

\section{Cuprins}

I. Sediul legal

II. Hotărârile judecătorești având ca obiect despăgubiri rezultate în urma concedierii nelegale pronunțate împotriva unor instituții sau autorități publice.

III. Inaplicabilitatea actelor normative privind suspendarea legală a executării silite și eșalonarea plății sumelor prevăzute prin hotărâri judecătorești având ca obiect despăgubiri rezultate în urma concedierii nelegale 85

IV. Concluzii 96

\section{Sediul legal}

În vederea menținerii sau al restabilirii echilibrului bugetar, legiuitorul național a adoptat de-a lungul timpului mai multe acte normative, acestea fiind în ordinea succesiunii în timp: OUG nr. 75/2008, privind stabilirea de măsuri pentru soluționarea unor aspecte financiare în sistemul justiției', OUG nr. 71/2009, privind plata unor sume prevăzute în titluri executorii având ca obiect acordarea de drepturi salariale personalului din sectorul bugetar², OUG nr. 99/2016, privind unele măsuri pentru salarizarea

\footnotetext{
${ }^{1}$ Publicată în M.of.: 462 din 20 iunie 2008.

2 Publicată în M.of.: 416 din 18 iunie 2009.
} 
personalului plătit din fonduri publice, prorogarea unor termene, precum și unele măsuri fiscal-bugetare3, OUG nr. 90/2017, privind unele măsuri fiscalbugetare, modificarea și completarea unor acte normative și prorogarea unor termene ${ }^{4}$, OUG nr. 114/2018, privind instituirea unor măsuri în domeniul investițiilor publice și a unor măsuri fiscal-bugetare, modificarea și completarea unor acte normative şi prorogarea unor termene ${ }^{5}$ și OUG nr. 130/2021, privind unele măsuri fiscal-bugetare, prorogarea unor termene, precum și pentru modificarea și completarea unor acte normative ${ }^{6}$.

Toate aceste acte normative au avut ca scop în esență eșalonarea la plată a sumelor prevăzute prin hotărâri judecătorești, având ca obiect acordarea unor drepturi de natură salarială în favoarea personalului din instituțiile și autoritățile publice, titluri devenite executorii. Aceste acte normative care au stabilit prorogarea unor termene de plată au drept scop declarat consolidarea capacității financiare și operaționale a statului, după cum este prezentat pe larg în expunerea de motive din cuprinsul acestor acte normative. Ele dispun suspendarea legală a executării silite a hotărârilor judecătorești și reglementează o procedură de executare după care se va realiza plata unor sume prevăzute prin hotărâri judecătorești având ca obiect acordarea unor drepturi de natură salarială stabilite în favoarea personalului din sectorul bugetar, devenite executorii.

\footnotetext{
3 Publicată în M.of.: 1.035 din 22 decembrie 2016.

4 Publicată în M.of.: 973 din 7 decembrie 2017.

5 Publicată în M.of.: 1116 din 29 decembrie 2018.

${ }^{6}$ Publicată în M.of.: 1202 din 18 decembrie 2021.
} 
Astfel, spre exemplu, conform art. 39 din OUG nr. 114/20187: „, (1) Plata sumelor prevăzute prin hotărâri judecătorești având ca obiect acordarea unor drepturi de natură salarială stabilite în favoarea personalului din instituțiile și autoritățile publice, devenite executorii în perioada 1 ianuarie 2019-31 decembrie 2021, se va realiza astfel: a) în primul an de la data la care hotărârea judecătorească devine executorie se plătește $5 \%$ din valoarea titlului executoriu; b) în al doilea an de la data la care hotărârea judecătorească devine executorie se plătește $10 \%$ din valoarea titlului executoriu; c) în al treilea an de la data la care hotărârea judecătorească devine executorie se plătește 25\% din valoarea titlului executoriu; d) în al patrulea an de la data la care hotărârea judecătorească devine executorie se plătește $25 \%$ din valoarea titlului executoriu; e) în al cincilea an de la data la care hotărârea judecătorească devine executorie se plătește $35 \%$ din valoarea titlului executoriu. (2) Procedura de plată eșalonată prevăzută la alin. (1) se aplică și în ceea ce privește plata sumelor prevăzute prin hotărâri judecătorești devenite executorii în perioada 1 ianuarie 2019-31 decembrie 2021, având ca obiect acordarea de daune-interese moratorii sub forma dobânzii legale pentru plata eșalonată a sumelor prevăzute în titluri executorii având ca obiect acordarea unor drepturi salariale personalului din sectorul bugetar. (3) În cursul termenului prevăzut la alin. (1), orice procedură de executare silită se suspendă de drept. (4) Sumele prevăzute la alin. (1), plătite în temeiul prezentei ordonanțe de urgență, se actualizează cu indicele prețurilor de consum comunicat de Institutul Național de Statistică. (5) La sumele actualizate în condițiile alin. (4) se acordă dobânda legală remuneratorie, calculată de la data la care hotărârea judecătorească a rămas executorie. (6) Prin ordin al ordonatorilor principali de credite va fi stabilită procedura de efectuare a plății titlurilor executorii, cu respectarea termenelor prevăzute la alin. (1).”

\footnotetext{
7 Prevederi similare se regăsesc și în art. VI. al OUG nr. 130/2021, privind unele măsuri fiscalbugetare, prorogarea unor termene, precum şi pentru modificarea şi completarea unor acte normative.
} 
II. Hotărârile judecătorești având ca obiect despăgubiri rezultate în urma concedierii nelegale pronunțate împotriva unor instituții sau autorități publice.

De regulă, în aceste litigii specifice dreptului muncii instanțele de judecată, în măsura în care apreciază că a avut loc o decizie nelegală de încetare a contractului individual de muncă, pronunță hotărâri judecătorești prin care admit acțiunea civilă formulată de către reclamant împotriva pârâtului, instituție sau autoritate publică, urmând a dispune anularea deciziei de încetare a contractului individual de muncă emisă de pârât, iar față de prevederile art. 80 din Codul muncii dispun reintegrarea în funcţia avută anterior emiterii deciziei menționate și obligarea pârâtului la plata unei despăgubiri egale cu salariile indexate, majorate și reactualizate, precum și cu celelalte drepturi de care reclamanta ar fi beneficiat, inclusiv plata contribuțiilor sociale aferente, începând cu data deciziei de încetare a contractului individual de muncă emisă de pârât și până la reintegrarea efectivă. Potrivit art. 274 C.m., hotărârile pronunțate în fond sunt definitive şi executorii de drept.

Ulterior, creditorii se adresează executorului judecătoresc solicitând punerea în executare silită împotriva debitorului a sumei integrale stabilite prin hotărârea judecătorească - titlu executoriu. În absența unei reglementări exprese în legislația muncii este aplicabil termenul de 3 ani de prescripție a executării ${ }^{8}$, stabilit de art. 706 alin. (1) C. pr. civ.

${ }^{8}$ A se vedea, R.R. POPEScu, Dreptul european al muncii: legislație, doctrină, jurisprudență, Ed. Hamangiu, București, 2021, p. 235. 
Debitorii, instituțiile și autorităţile publice formulează, de regulă, contestație la executare, solicitând, suspendarea executării silite demarate în dosarul execuțional, anularea încheierii de încuviințare a executării silite emise de judecătorie, anularea tuturor actelor de executare privind executarea silită începută împotriva contestatorului și eventual întoarcerea executării silite prin obligarea creditorului la restituirea către contestator a sumelor consemnate la dispoziția executorului judecătoresc ${ }^{9}$. În esență, intimații, instituțiile şi autorităţile publice, invocă drept argument principal al contestației la executoare incidența actelor normative care prevăd faptul că drepturile de natură salarială ce fac obiectul executării silite se plătesc eşalonat, în tranşe.

III. Inaplicabilitatea actelor normative privind suspendarea legală a executării silite și eșalonarea plății sumelor prevăzute prin hotărâri judecătorești având ca obiect despăgubiri rezultate în urma concedierii nelegale

La o primă vedere s-ar părea că aceste acte normative menționate mai sus vizează toate situațiile în care este vorba despre sume prevăzute prin hotărâri judecătorești având ca ca obiect acordarea unor drepturi de natură salarială stabilite în favoarea personalului din instituțiile și autoritățile publice.

9 A se vedea în acest sens Jud. Cluj-Napoca, sent. civ. nr. 2956/2021 din data de 28 aprilie 2021, (nepublicată).

\section{5}


Problema care se pune este dacă drepturile obținute de către creditori prin aceste hotărâri judecătorești sunt drepturi de natură salarială sau asimilate salarïlor, fiind derivate dintr-un raport de muncă salarizat din fonduri publice şi dacă le sunt aplicabile pe cale de consecinţă actele normative care impun eșalonarea la plată a sumelor obținute astfel de către creditori.

Potrivit art. 76 alin. (1) din Codul fiscal: „, sunt considerate venituri din salarii toate veniturile în bani şi/sau în natură obținute de o persoană fizică rezidentă ori nerezidentă ce desfăşoară o activitate în baza unui contract individual de muncă, a unui raport de serviciu, act de detaşare sau a unui statut special prevăzut de lege, indiferent de perioada la care se referă, de denumirea veniturilor ori de forma sub care ele se acordă, inclusiv indemnizațiile pentru incapacitate temporară de muncă acordate persoanelor care obțin venituri din salarii și asimilate salariilor ${ }^{10}$. Art. 76 alin. (2) lit. s) din Codul fiscal prevede că sunt considerate asimilate salariilor, din punct de vedere fiscal: orice alte sume sau avantaje în bani ori în natură, urmând ca, la alineatul următor să fie redate cu titlu exemplificativ, iar nu limitativ, categorii de astfel de sume sau avantaje. Potrivit normelor metodologice aplicabile Codului fiscal, în sensul art. 76 alin. (1) și (2) din Codul fiscal, veniturile brute din salarii sau asimilate salariilor cuprind totalitatea sumelor încasate și/sau contravaloarea veniturilor în natură primite ca urmare a unei relații contractuale de muncă, raport de serviciu, act de detaşare, precum și orice sume de natură salarială primite în baza unor statute speciale prevăzute de lege, indiferent de perioada la care se referă. Or, despăgubirilor obținute

\footnotetext{
${ }^{10}$ Legea nr. 227/2015 privind Codul fiscal, publicată în M.of.: 688 din 10 septembrie 2015, cu
} modificările şi completările ulterioare. 
de către creditori, egale cu salariile indexate, majorate şi reactualizate, au rezultat ca urmare a unui raport de muncă, desfăşurat în baza unui contract individual de muncă și se calculează raportat la salariul de bază prevăzut de lege pentru categoria sa de personal plătit din fonduri publice.

Pe cale de consecință, în lumina legislației fiscale și acestor titluri executorii, reprezentate de hotărâri judecătorești, având ca obiect despăgubiri rezultate în urma concedierii nelegale, ar urma să le fie aplicabile actele normative privind eșalonarea plății sumelor devenite executorii iar o eventuală executare silită ar putea avea loc numai fracţionat, pentru o parte din suma care devine exigibilă și nu pentru întregul sumei prevăzută în titlul executoriu.

La o analiză mai atentă, o astfel de interpretare este eronată pentru argumentele pe care le vom dezvolta în cele ce urmează.

În primul rând, toate aceste acte normative se referă la hotărâri judecătorești având ca obiect „acordarea unor drepturi de natură salarială stabilite în favoarea personalului din instituțiile și autoritățile publice”, însă natura juridică a dreptului de creanța recunoscut prin astfel de hotărâri judecătorești este alta.

Natura juridică a drepturilor câştigate de către creditori print titlurile executorii nu reprezintă drepturi de natură salarială și nici despăgubiri moratorii ci, despăgubiri compensatorii pentru încetarea nelegală a raporturilor de muncă ${ }^{11}$. Drept consecință, nu se poate, din punct de vedere

\footnotetext{
${ }^{11}$ A se vedea în acest sens: Jud. Cluj-Napoca, sent. civ. nr. 950/2021 din data de 15 februarie 2021, (nepublicată); Jud. Cluj-Napoca, sent. civ. nr. 2956/2021 din data de 28 aprilie 2021, (nepublicată).
} 
juridic, susține faptul că dispozițiile ordonanțelor de urgență mai sus amintite ar fi aplicabile.

Plata eșalonată a acestor creanțe a fost repudiată şi de către jurisprudența mai veche, considerându-se faptul că dispozițiile OUG 71/2009 nu se aplică în situația despăgubirilor egale cu salariile indexate, majorate și actualizate și celelalte drepturi, de care ar fi beneficiat salariatul, dacă nu ar fi fost concediat nelegal ${ }^{12}$.

Astfel, despăgubirile oferite salariatului în caz de concediere nelegală, nu trebuie confundate cu drepturile salariale, cuprinse în art. 159 C.m., ce au un regim juridic diferit, iar în acest sens, este exclusă aplicarea acestor ordonanțe pentru despăgubirile acordate conform art. 80 C.m., în caz de concediere nelegală. Prin salariu, conform art. 159 din Codul muncii, se înțelege salariul de bază, indemnizațiile, sporurile, precum și alte adaosuri, în schimb, potrivit art. 80 C.m., în caz de concediere nelegală se acordă despăgubiri, care deși sunt egale cu salariile ce trebuiau plătite, indexate corespunzător, nu trebuie confundate ca natură juridică cu drepturile salariale prevăzute de Codul muncii.

De asemenea, Minuta din data de 15 iunie 2018, emisă în urma Întâlnirii președinților secțiilor pentru cauze privind conflictele de muncă și asigurări sociale ai curților de apel ${ }^{13}$, afirmă faptul că „salariatul va fi repus în

\footnotetext{
${ }^{12}$ A se vedea Trib. Argeș, secția civilă, dec. civ. nr. 750 din 20 martie 2013,- Concediere ilegală. Despăgubiri. Inaplicabilitatea OUG nr. 71/2009, speță trimisă în rezumat de judecător V. Terzea, în RRES, nr. 2/2013 pp. 139-144.

13 Întâlnirea președinților secțiilor pentru cauze privind conflicte de muncă și asigurări sociale ai curților de apel, Minuta, [Institutul NaȚional al Magistraturi org.], [online], http://inmlex.ro/fisiere/d 2444/Minuta\%20intalnire\%20litigii\%20de\%20munca\%2015\%20iunie\%202 018.pdf, București, 15 iunie 2018.
} 
situația anterioară acestei decizii, dar nu prin aplicarea extensivă a art. 80 alin. (1) C. muncii, ci prin aplicarea principiului de drept comun privind repunerea părților în situația anterioară.”

Interpretarea actelor normative expuse, în sens contrar, ar determina o discriminare nepermisă, suplimentară, salariatului concediat nelegal care, deși repus în situația anterioară, nu și-ar putea încasa ex tunc salariul, în aceleași condiții precum un salariat în funcţie.

O asemenea discriminare este interzisă și de prevederile art. 16 alin. (1), din cadrul Constituției României ${ }^{14}$, prin care se prevede faptul că „cetățenii sunt egali în fața legii și a autorităților publice, fără privilegii și fără discriminări”, coroborat cu art. 41 alin. (2) din cadrul aceluiași act normativ care prevede că:

„salariații au dreptul la măsuri de protecţie socială. Acestea privesc securitatea și sănătatea salariaților, regimul de muncă al femeilor și al tinerilor, instituirea unui salariu minim brut pe țară, repausul săptămânal, concediul de odihnă plătit, prestarea muncii în condiții deosebite sau speciale, formarea profesională, precum și alte situații specifice, stabilite prin lege."

Pentru a fi în deplină concordanță cu spiritul și litera legii, se impune a se achita global suma, constând în despăgubirile enunțate, salariatului repus în funcție, în urma unei concedieri nelegale, respectându-se astfel, inclusiv art. 6 alin. 1 din Convenția Europeană a Drepturilor Omului, respectiv dreptul la un proces echitabil. În acest sens, s-a pronunțat Curtea și

\footnotetext{
14 Publicată în M.of.: 233 din 21 noiembrie 1991, modificată și completată prin Legea de revizuire a Constituției României nr. 429/2003, publicată în M.of.: 758 din 29 octombrie 2003, republicată de Consiliul Legislativ.
} 
în cadrul hotărârilor pronunțate în Cauza Șandor c. România din 24 martie 2005¹5, respectiv Cauza Hornsby c. Grecia ${ }^{16}$ din 19 martie 1997.

Astfel, în cadrul celei dintâi hotărâri amintite, se afirmă faptul că, garanțiile prevăzute la art. 6 din Convenție sunt aplicabile și în faza executării silite a hotărârii judecătorești, întrucât procesul civil include și etapa executării silite, având în vedere că, în caz contrar, respectiv dacă ordinea juridică a unui stat ar permite ca o hotărâre definitivă și obligatorie să rămână fără efect în detrimentul unei părți, dreptul de acces la o instanță ar deveni iluzoriu.

Pe de-altă parte, în cuprinsul celei de-a doua hotărâri, se relevă faptul că, este excesiv și, prin urmare, contrar dreptului la un proces echitabil să se pretindă unui creditor al statului să recurgă la o procedură de executare silită pentru a-și realiza dreptul de creanță stabilit într-o procedură judiciară.

În același timp, art. 6 al Convenției europene a drepturilor omului face referire la respectarea unui termen rezonabil, pentru punerea în executare a unei hotărâri judecătorești definitive.

În continuare, în susținerea celor expuse, este necesar a fi subliniat faptul că drepturile acordate în baza unei hotărâri judecătorești, persoanei reîncadrate în funcție, în urma concedierii nelegale, nici nu pot fi catalogate ca fiind drepturi de natură salarială, deoarece persoana respectivă nici nu mai avea calitatea de angajat/salariat, contractul de muncă fiind desființat de către angajator.

\footnotetext{
15 Publicată în M.of.: 1048 din 25 noiembrie 2005.

16 A se vedea Hornsby $v$. Greece (Article 50), 1 April 1998, disponibilă la adresa: http://hudoc.echr.coe.int/app/conversion/docx/?library=ECHR\&id=001 58153\&filename=CASE\%20OF\%20HORNSBY\%20v.\%20GREECE\%20.
}

\section{0}


Astfel, drepturile salariale, ca expresie a muncii prestate, se cuvin angajatului numai pentru perioada în care acesta se află în raporturi de muncă cu angajatorul, nu și ulterior acestei perioade ${ }^{17}$. Or, creditorilor le-au fost acordate aceste despăgubiri de către instanțele judecătorești tocmai pentru că angajatorul a încetat contractul de muncă în mod nelegal.

Despăgubirile au o cu totul o altă cauză decât drepturile salariale şi acoperă prejudiciul suferit în urma concedierii și reprezintă o sancțiune $a$ unui comportament nelegal al angajatorului. Acestea se acordă chiar și în situația în care salariatul concediat nelegal s-a angajat între timp la alt angajator, deoarece acestea au cu totul o altă cauză decât drepturile salariale aferente noului loc de muncă, acestea din urmă reprezentând contravaloarea muncii prestate în folosul noului angajator, pe când despăgubirile acoperă prejudiciul suferit în urma concedierii.

Totodată, așa cum s-a evidențiat și în literatura de specialitate, despăgubirile nu reprezintă o contraprestație a muncii ci o sancțiune a unui comportament nelagal al anagajatorului ${ }^{18}$.

În plus, ordonanțele de urgență mai sus amintite au în vedere plata unor sume prevăzute în titluri executorii, având ca obiect acordarea de drepturi salariale ale personalului din sectorul bugetar stabilite prin hotărâri judecătorești, respectiv alte drepturi decât cele pe care angajații le primeau în mod obișnuit pentru munca prestată. Așadar, prin folosirea sintagmei „acordarea”, legiuitorul are în vedere drepturi de care angajatul nu a mai

\footnotetext{
17 A se vedea, A. ȚicleA, Tratat de dreptul muncii, Ed. Universul Juridic, București, 2013, p. 501.

18 Idem, Tratat privind încetarea raporturilor de muncă, Ed. Universul Juridic, București, 2018, p. 610.
} 
beneficiat anterior, drepturi care au fost acordate prin hotărâri judecătorești şi care au fost suplimentare faţă de cele acordate personalului bugetar.

Pe de altă parte salariul se datorează pentru munca prestată. Acesta ar fi motivul pentru care diminuarea orelor de muncă sau concediul, fac să se modifice obligația de plată a salariului sau să se suspende, caz în care se plătește o indemnizație, nu salariu. Or salariatul concediat nelegal nu prestează muncă pe perioada cuprinsă între data de la care îi încetează contractul individual de muncă prin concediere și data reintegrării sale pe post. Ceea ce i se datorează, de angajator, nu ar putea fi așadar un salariu în lipsa muncii - ci drepturi bănești egale cu salariul la care ar fi fost îndreptățit, natura drepturilor e aşadar diferită, iar raportarea la salariu e doar o modalitate de estimare a prejudiciului.

Dincolo de asta, despăgubirea se extinde și asupra valorii „celorlalte drepturi de care reclamantul nu a beneficiat” deci nu ar putea fi calificată ca un drept de natură salarială întrucât nu ține de natura salariului plata unei asemenea despăgubiri și nici despăgubirea nu se rezumă doar la plata unui salariu.

Poate că cel mai puternic argument în favoarea inaplicabilității actelor normative privind eşalonarea plății sumelor prevăzute prin hotărâri judecătorești având ca obiect despăgubiri rezultate în urma concedierii nelegale îl reprezintă însă considerentele decisive ale Deciziei Curţii Constituţionale nr. 355/2011 19.

Prin această decizie Curtea Constituțională s-a pronunțat asupra excepției de neconstituționalitate a prevederilor art. 1 alin.(1) din

19 Publicată în M.of.: 500 din 13 iulie 2011. 
OUG nr. 71/2009 privind plata unor sume prevăzute în titluri executorii având ca obiect acordarea de drepturi salariale personalului din sectorul bugetar. $\mathrm{Cu}$ toate că a respins ca inadmisibilă excepția de neconstituționalitate, având în vedere că aspectele invocate de autorul excepției, nu vizează o problemă ce ține de contenciosul constituțional, ci este o problemă de interpretare și aplicare a legii, ce este atributul exclusiv al instanțelor judecătorești, Curtea Constituțională a făcut o analiză detaliată a situației juridice deduse judecății.

Deși analiza Curții se referă la OUG nr. 71/2009 și între timp au apărut mai multe acte normative diferite, principiile reținute în cuprinsul Deciziei Curții Constituționale nr. 355/2011 se aplică și în ceea ce privește restul ordonanțelor menționate în cuprinsul prezentului articol deoarece toate aceste ordonanțe vizează aceeași materie, respectiv acestea reglementează o procedură de executare, după care se va realiza plata unor sume prevăzute prin hotărâri judecătorești având ca obiect acordarea unor drepturi de natură salarială stabilite în favoarea personalului din sectorul bugetar, devenite executorii.

Având în vedere că principiile reținute în considerentele Deciziei Curții Constituționale nr. 355/2011 urmează să se aplice în opinia noastră și în ceea ce privește restul ordonanțelor menționate în cuprinsul prezentului articol apreciem că este important să le reproducem mai jos in extenso.

Astfel, Curtea Constituțională reține că:

„deși prevederile Ordonanței de urgență a Guvernului nr. 71/2009, cu modificările și completările ulterioare, nu fac diferența explicită între drepturile salariale obținute prin sentințe judecătorești definitive și executorii în cazul salariaților din instituțiile publice care au obținut o majorare sau o completare a acestor drepturi, prin care 
li s-au acordat anumite sporuri, prime etc. la salariul stabilit prin contractul individual de muncă, și drepturile salariale cuprinse în contractul individual de muncă, se poate reține că întinderea de aplicare a acesteia, aşa cum de altfel reiese şi din titlul său, este circumscrisă la hotărâri judecătorești prin care au fost acordate drepturi de natură salarială stabilite în favoarea personalului din sectorul bugetar și nu la hotărâri judecătorești prin care instituțiile publice sunt obligate la plata unor sume de bani în favoarea salariaților ca urmare a concedierilor efectuate în mod netemeinic sau nelegal."

Prin urmare, una este situația în care anumite categorii de salariaţi au sesizat instanțele judecătorești pentru a obține aplicarea unor dispoziții legale prin care să obțină o majorare a drepturilor salariale, majorare care le-a fost refuzată de angajator tocmai pe motivul că acele dispoziții legale nu se aplică, și alta este situația în care un salariat a sesizat instanța pentru ca aceasta să constate concedierea sa nelegală și să dispună revenirea la situația anterioară, prin urmare să restabilească ordinea de drept încălcată.

În prima situație este vorba de obținerea unor drepturi de natură salarială care nu au fost acordate prin procedura normală și nu este cazul a distinge motivele pentru care angajatorii - instituții publice - nu au acordat aceste drepturi, iar drepturile astfel obținute grevează bugetul public fără ca Guvernul să aibă posibilitatea să angajeze cheltuieli de natură salarială prin bugetul de stat.

Doar pentru această stare de lucruri Guvernul a emis Ordonanța de urgență a guvernului nr. 71/2009, care a fost modificată prin Ordonanța de urgență a guvernului nr. 18/2010 și prin Ordonanța de urgență a guvernului nr. 45/2010, prin care a eșalonat acordarea acestor drepturi cuprinse în hotărâri judecătorești pe o perioadă de timp care să poată fi susținută de resursele financiare ale bugetului.

\section{4}


De altfel, curtea constată că prima eșalonare a plății sumelor prevăzute în titlurile executorii a fost reglementată prin Ordonanța de urgență a guvernului nr. 75/2008 privind stabilirea de măsuri pentru soluționarea unor aspecte financiare în sistemul justiției, având ca obiect acordarea unor drepturi de natură salarială stabilite în favoarea personalului din sistemul justiției.

Ulterior acestui act normativ a fost adoptată Ordonanța de urgență a guvernului nr. 71/2009 privind plata unor sume prevăzute în titluri executorii având ca obiect acordarea de drepturi salariale personalului din sectorul bugetar, ce reglementează eșalonarea plății sumelor prevăzute în titlurile executorii, având ca obiect acordarea unor drepturi de natură salarială stabilite în favoarea personalului din sectorul bugetar.

În consecință, ținând cont de intenția legiuitorului, este evident că Ordonanța de urgență a guvernului nr. 71/2009 privind plata unor sume prevăzute în titluri executorii având ca obiect acordarea de drepturi salariale personalului din sectorul bugetar nu vizează ipoteza art.78 din Legea nr. 53/2003 - Codul muncii, ci ipoteza unor drepturi salariale suplimentare obținute prin legi speciale.

II. Persoanele care au câștigat în instanță drepturi salariale ca urmare a concedierii, după ce instanța de judecată a stabilit că aceasta a fost efectuată în mod netemeinic sau nelegal, aşa cum este prevăzut în art. 78 din Legea nr. 53/2003 - Codul muncii, se află în altă situație juridică decât cea vizată de Ordonanța de urgență a guvernului nr. 75/2008 și de Ordonanța de urgență a guvernului nr. 71/2009.

Potrivit prevederilor invocate din Legea nr. 53/2003 - Codul muncii, în cazul în care concedierea a fost efectuată în mod netemeinic sau nelegal, 
instanța va dispune anularea ei și va obliga angajatorul la plata unei despăgubiri egale cu salariile indexate, majorate şi reactualizate şi cu celelalte drepturi de care ar fi beneficiat salariatul, iar la solicitarea salariatului instanța care a dispus anularea concedierii va repune părțile în situația anterioară emiteri actului de concediere.

Potrivit principiului de drept quod nullum est, nullum producit effectum, consecințele juridice ale aplicării sancțiunii nulității constau, pe de o parte, în lipsirea actului de efectele contrarii normelor ce ar fi trebuit avute în vedere la încheierea sa și, pe de altă parte, în restabilirea legalității.

Or, restabilirea legalităţii, ca efect al nulităţii, implică restabilirea situației anterioare. Aceasta presupune ca persoana în cauză, ca urmare a anulării concedierii, să ajungă la situația de a-și recupera toate drepturile de care a fost deposedată prin actul nelegal al angajatorului, respectiv să își recupereze statutul de salariat, funcția sau postul, locul de muncă, să primească salariul retroactiv cu titlu de despăgubiri și celelalte drepturi de care ar fi beneficiat."

\section{Concluzii}

În opinia noastră, este exclusă incidența actelor normative care stipulează eșalonarea la plată a sumelor prevăzute prin hotărâri judecătorești în favoarea personalului din instituțiile și autorităţile publice în cazul despăgubirilor acordate conform art. 80 C.m., în caz de concediere nelegală.

Natura juridică a drepturilor câștigate de către creditori print titlurile executorii nu reprezintă drepturi de natură salarială ci despăgubiri compensatorii pentru încetarea nelegală a raporturilor de muncă. 
Restabilirea legalităţii, ca efect al nulităţii, implică restabilirea situației anterioare care presupune ca persoana în cauză, ca urmare a anulării concedierii, să ajungă la situația de a-și recupera toate drepturile de care a fost deposedată prin actul nelegal al angajatorului, respectiv să primească salariul retroactiv cu titlu de despăgubire.

În concluzie, actele normative care stabilesc plata eșalonată a drepturilor de natură salarială stabilite în favoarea personalului din instituțiile și autorităţile publice și care suspendă executarea silită a hotărârilor judecătorești nu au aplicabilitate în ipoteza drepturilor câștigate de către personalul din instituțiile și autoritățile publice prin titluri executorii ce reprezintă despăgubiri compensatorii pentru încetarea nelegală a raporturilor de muncă.

În aceste cazuri sumele datorate creditorilor urmează să fie achitate integral, o altă interpretare fiind contrară jurisprudenței Curții Constituționale și dreptului la un proces echitabil într-un termen rezonabil, în sensul art. 6 par. 1 din Convenția Europeană a Drepturilor Omului. 